\title{
Optimal Management of Anticoagulation Therapy in Asian Patients With Atrial Fibrillation
}

\author{
Wen-Han Cheng, MD; Yi-Hsin Chan, MD; Jo-Nan Liao, MD; \\ Ling Kuo, MD; Shih-Ann Chen, MD; Tze-Fan Chao, MD
}

\begin{abstract}
Stroke prevention is the cornerstone of management of atrial fibrillation (AF), and non-vitamin $\mathrm{K}$ antagonist oral anticoagulants (NOACs) are commonly prescribed. Because routine monitoring of anticoagulant effects of NOACs is not necessary, appropriate dosing following the criteria of each NOACs defined in pivotal randomized trials is important. Real-world data demonstrate that underdosing NOACs is associated with a higher risk of ischemic stroke without a lower risk of major bleeding. Furthermore, renal function of AF patients should be assessed using the Cockcroft-Gault formula to prevent overestimation that could result in overdosing of NOACs. The assessment of bleeding risk is important, and the HAS-BLED score should be used to help identify patients at high risk of bleeding (HAS-BLED score $\geq 3$ ). Moreover, the HAS-BLED score should be reassessed at periodic intervals to address potentially modifiable bleeding risk factors because bleeding risks of AF patients are not static. When managing NOAC-related bleeding episodes, the possibility of occult malignancies (e.g., grastrointestinal [GI] tract cancers for patients experiencing Gl bleeding and bladder cancer for patients with hematuria) should be kept in mind. Addressing all of these issues is crucial to achieving better clinical outcomes for anticoagulated AF patients. More efforts are necessary to incorporate clear and easy-to-follow recommendations about optimal management of anticoagulation into the guidelines to improve AF patient care.
\end{abstract}

Key Words: Atrial fibrillation; Ischemic stroke; Malignancy; Non-vitamin K antagonist oral anticoagulation

A trial fibrillation (AF), the most common arrhythmia in daily medical practice, could potentially cause blood stasis and increase the risk of thromboembolism, ischemic stroke (IS), dementia, heart failure, myocardial infarction (MI), and death compared with patients without AF. ${ }^{1}$ In addition, AF-related stroke has higher morbidity/mortality rates. ${ }^{2}$ Although the management of AF has changed markedly in the past 2 decades, stroke prevention with oral anticoagulants (OACs) remains the foundation of holistic care of AF.,4

Among the OACs, non-vitamin $\mathrm{K}$ antagonist OACs (NOACs), including dabigatran, rivaroxaban, apixaban, and edoxaban, have emerged as an alternative and effective choice for stroke prevention worldwide. ${ }^{5,6}$ Compared with warfarin, NOACs possess better efficacy/safety ratios without the need for routine drug concentration monitoring, and less food and drug interactions. ${ }^{7}$ In fact, the introduction of NOACs has changed the field of stroke prevenion in Asia and improved the clinical outcomes of Asian AF patients. ${ }^{6.8}$ However, the appropriate use of NOACs still remains unsatisfactory, and a considerable propotion of patients still do not receive OACs. Although current clinical guidelines have provided overall recommendations on the initiation and general principles of NOAC use, ${ }^{5,9}$ realworld analyses have revealed that several factors might cause underuse or inproper use of NOACs. ${ }^{10,11}$ These factors include older age, worse renal function, and previous bleeding events, ${ }^{11}$ and hinder optimal management of anticoagulation therapy.

Here we aim to provide an overview of optimal management of anticoagulation therapy in Asian AF patients, focusing on appropriate dosing of NOACs, adoption of the corrent renal function equations to determine the dosing of NOACs, and management of NOAC-related bleeding.

\section{Importance of Prescribing On-Label Dosing of NOACs}

Although the appropriate dosages of NOACs have been clearly defined by randomized controlled trials, real-world

Received April 28, 2021; accepted April 28, 2021; J-STAGE Advance Publication released online June 5, 2021

Division of Cardiology, Department of Medicine, Taipei Veterans General Hospital, Taipei (W.-H.C., J.-N.L., L.K., S.-A.C., T.-F.C.); Institute of Clinical Medicine, and Cardiovascular Research Center, National Yang Ming Chiao Tung University, Taipei (W.-H.C., J.-N.L., L.K., S.-A.C., T.-F.C.); The Cardiovascular Department, Chang Gung Memorial Hospital, Linkou, Taoyuan (Y.-H.C.); College of Medicine, Chang Gung University, Taoyuan (Y.-H.C.); Microscopy Core Laboratory, Chang Gung Memorial Hospital, Linkou, Taoyuan (Y.-H.C.); and Cardiovascular Center, Taichung Veterans General Hospital, Taichung (S.-A.C.), Taiwan

The first two authors contributed equally to this review article (W.-H.C., Y.-H.C.).

Mailing address: Tze-Fan Chao, MD, Division of Cardiology, Department of Medicine, Taipei Veterans General Hospital, No. 201, Sec. 2, Shih-Pai Road, Taipei, Taiwan. E-mail: eyckeyck@gmail.com

All rights are reserved to the Japanese Circulation Society. For permissions, please e-mail: cj@j-circ.or.jp ISSN-1346-9843 


\begin{tabular}{|c|c|c|c|c|c|c|}
\hline $\begin{array}{l}\text { Clinical } \\
\text { study }\end{array}$ & Study type & $\begin{array}{l}\text { NOAC(s) } \\
\text { studied }\end{array}$ & $\begin{array}{l}\text { Definition of } \\
\text { underdosing } \\
\text { NOAC(s) }\end{array}$ & $\begin{array}{l}\text { Age of the } \\
\text { underdosing } \\
\text { group }\end{array}$ & $\begin{array}{l}\text { Total no. of patients } \\
\text { receiving NOAC(s) }\end{array}$ & $\begin{array}{l}\text { Main findings (underdosing } \\
\text { group vs. appropriate } \\
\text { dosing: Reference) }\end{array}$ \\
\hline $\begin{array}{l}\text { Murata et al } \\
(2019)^{18}\end{array}$ & $\begin{array}{l}\text { Prospective } \\
\text { registry }\end{array}$ & $\begin{array}{l}\text { Dabigatran } \\
\text { Rivaroxaban } \\
\text { Apixaban } \\
\text { Edoxaban }\end{array}$ & $\begin{array}{l}\text { Low-dose of NOACs } \\
\text { despite standard } \\
\text { dosage criteria being } \\
\text { met }\end{array}$ & $\begin{array}{l}71.2 \pm 8.2 \\
\text { years }\end{array}$ & $\begin{array}{l}\text { 1,658 } \\
\text { (Appropriate dosing: } \\
1,223[74 \%] ; \\
\text { Underdosing: } 369 \\
\text { [22\%]; } \\
\text { Overdosing: } 66[4 \%] \text { ) }\end{array}$ & $\begin{array}{l}\text { Stroke/SE: } 1.02 \text { event/100 } \\
\text { patient-years; aHR: } 0.851 \\
(0.391-1.746) \\
\text { Major bleeding: } 0.64 \\
\text { event/100 patient-years; } \\
\text { aHR: } 0.474 \text { (0.185-1.071) }\end{array}$ \\
\hline $\begin{array}{l}\text { lkeda et al } \\
(2019)^{19}\end{array}$ & $\begin{array}{l}\text { Prospective } \\
\text { registry }\end{array}$ & Rivaroxaban & $\begin{array}{l}\text { Rivaroxaban: } 10 \mathrm{mg} \\
\text { daily for patients with } \\
\text { an eGFR }>50 \mathrm{~mL} / \mathrm{min}\end{array}$ & $\begin{array}{l}68.0 \pm 21.2 \\
\text { years }\end{array}$ & $\begin{array}{l}\text { 6,521 } \\
\text { (Appropriate dosing: } \\
4,185[64 \%] ; \\
\text { Underdosing: } 2,336 \\
\text { [36\%]) }\end{array}$ & $\begin{array}{l}\text { Stroke/non-CNS SE/MI: } 2.15 \\
\text { events/100 patient-years; } \\
\text { HR: } 1.45 \text { (1.10-1.91) } \\
\text { Major bleeding: } 1.34 \\
\text { events/100 patient-years; } \\
\text { HR: } 0.82(0.61-1.11)\end{array}$ \\
\hline $\begin{array}{l}\text { Cheng et al } \\
(2019)^{11}\end{array}$ & $\begin{array}{l}\text { Retrospective } \\
\text { database }\end{array}$ & Rivaroxaban & $\begin{array}{l}\text { Rivaroxaban: } 10 \mathrm{mg} \\
\text { daily for patients with } \\
\text { an eGFR }>50 \mathrm{~mL} / \mathrm{min}\end{array}$ & $\begin{array}{l}79.1 \pm 11.2 \\
\text { years }\end{array}$ & $\begin{array}{l}2214 \\
\text { (Appropriate dosing: } \\
1,630 \text { [74\%]; } \\
\text { Underdosing: } 584 \\
\text { [26\%]) }\end{array}$ & $\begin{array}{l}\text { IS: } 2.82 \text { events/100 patient- } \\
\text { years; aHR: } 2.75(1.62-4.69) \\
\text { Intracranial hemorrhage: } 1.16 \\
\text { events/100 patient-years; } \\
\text { aHR: } 0.62(0.32-1.20)\end{array}$ \\
\hline $\begin{array}{l}\text { Lee et al } \\
(2020)^{20}\end{array}$ & $\begin{array}{l}\text { Retrospective } \\
\text { database }\end{array}$ & $\begin{array}{l}\text { Dabigatran } \\
\text { Rivaroxaban } \\
\text { Apixaban } \\
\text { Edoxaban }\end{array}$ & $\begin{array}{l}\text { The following dosing } \\
\text { of NOACs without } \\
\text { meeting the dosage } \\
\text { reduction criteria } \\
\text { Dabigatran: } 110 \mathrm{mg} \\
\text { twice daily } \\
\text { Rivaroxaban: } 15 \mathrm{mg} \\
\text { once daily } \\
\text { Apixaban: } 2.5 \mathrm{mg} \\
\text { twice daily } \\
\text { Edoxaban: } 30 \mathrm{mg} \\
\text { twice daily }\end{array}$ & $\begin{array}{l}70.9 \pm 8.2 \\
\text { years }\end{array}$ & $\begin{array}{l}3,733 \\
\text { (Appropriate dosing: } \\
2,650[71 \%] ; \\
\text { Underdosing: } 733 \\
\text { [20\%]; } \\
\text { Overdosing: } 226[6 \%] \text { ) }\end{array}$ & $\begin{array}{l}\text { Thromboembolism: } 2.73 \% \\
\text { patients/year; aHR: } 3.12 \\
\text { (1.12-8.67) } \\
\text { Major bleeding: } 1.46 \% \\
\text { patients/year; aHR: } 2.24 \\
(0.62-8.17)\end{array}$ \\
\hline $\begin{array}{l}\text { Chan et al } \\
(2020)^{21}\end{array}$ & $\begin{array}{l}\text { Retrospective } \\
\text { database }\end{array}$ & $\begin{array}{l}\text { Dabigatran } \\
\text { Rivaroxaban } \\
\text { Apixaban } \\
\text { Edoxaban }\end{array}$ & $\begin{array}{l}\text { Following dosing of } \\
\text { NOACs without } \\
\text { meeting the dosage } \\
\text { reduction criteria. } \\
\text { Dabigatran: } 110 \mathrm{mg} \\
\text { twice daily } \\
\text { Rivaroxaban: } 15 \mathrm{mg} \\
\text { once daily with an } \\
\text { eGFR }>50 \mathrm{~mL} / \mathrm{min} \\
\text { Apixaban: } 2.5 \mathrm{mg} \\
\text { twice daily } \\
\text { Edoxaban: } 30 \mathrm{mg} \\
\text { twice daily or } 15 \mathrm{mg} \\
\text { once daily }\end{array}$ & $\begin{array}{l}71.7 \pm 69.4 \\
\text { years }\end{array}$ & $\begin{array}{l}11,275 \\
\text { (Appropriate dosing: } \\
7,764 \text { [69\%]; } \\
\text { Underdosing: } 2,999 \\
\text { [27\%]; } \\
\text { Overdosing: } 512[4 \%] \text { ) }\end{array}$ & $\begin{array}{l}\text { IS/SE: } 2.20 \% \text { patients/year; } \\
\text { aHR: } 1.59(1.25-2.02) \\
\text { Major bleeding: } 0.46 \% \\
\text { patients/year; aHR: } 0.80 \\
(0.50-1.27)\end{array}$ \\
\hline $\begin{array}{l}\text { Lee et al } \\
(2021)^{22}\end{array}$ & $\begin{array}{l}\text { Retrospective } \\
\text { database }\end{array}$ & Apixaban & $\begin{array}{l}\text { Apixaban: } 2.5 \mathrm{mg} \\
\text { twice daily and did } \\
\text { not fulfill the dose } \\
\text { reduction criteria }\end{array}$ & $\begin{array}{l}73.7 \pm 7.7 \\
\text { years }\end{array}$ & $\begin{array}{l}\text { 7,084 } \\
\text { (Appropriate dosing: } \\
\text { 4,194 [59\%]; } \\
\text { Underdosing: } 2,890 \\
{[41 \%] \text { ) }}\end{array}$ & $\begin{array}{l}\text { IS: } 2.11 \text { events/100 patient- } \\
\text { years; aHR: } 1.38(1.06-1.81) \\
\text { Major bleeding: } 1.09 \\
\text { events/100 patient-years; } \\
\text { aHR: } 0.99(0.70-1.42)\end{array}$ \\
\hline
\end{tabular}

$\mathrm{AF}$, atrial fibrillation; aHR, adjusted hazard ratio; CNS, central nervous system; eGFR, estimated glomerular filtration rate; IS, ischemic stroke; MI, myocardial infarction; NOAC, non-vitamin K antagonist oral anticoagulant; SE, systemic embolism.

data reveal that underdosing is not uncommon, and has been reported in up to $50 \%$ of $\mathrm{AF}$ patients treated with NOACs. ${ }^{12-16}$ In the ORBIT-AF (Outcomes Registry for Better Informed Treatment of Atrial Fibrillation) II registry, nearly one-eighth of US patients were under-dosed with NOACs, resulting in more cardiovascular hospitalizations without significant declines in major bleeding. ${ }^{17}$

In Asia, underdosing of NOACs is even more common under concerns of the higher risk of bleeding for Asian AF patients. Published studies investigating the association between different dosing of NOACs and risk of clinical outcomes in Asian AF patients are summarized in Table 1.11,18-22 Most of these studies, except for that performed by Murata et al, ${ }^{18}$ consistently showed a higher risk of IS or systemic embolism (SE) for off-label underdosing of NOACs, while overdosing NOACs was associated with a higher risk of bleeding (Figure 1). Taking the study performed by Chan et al, which enrolled 11,275 Taiwanese AF patients receiving NOACs, for example, $\approx 27 \%$ and $\approx 5 \%$ of them were treated with underdosing and overdosing of NOACs, respectively. ${ }^{21}$ Compared with on-label dosing, underdosing of NOACs was associated with a significantly higher risk of IS/SE (hazard ratio [HR] 1.59; 95\% confidence interval [CI] 1.25-2.02; $\mathrm{P}<0.001)$, whereas overdosing NOACs was associated with a significantly higher risk of major bleeding (adjusted HR 2.01; 95\% CI 1.13-3.56; $\mathrm{P}=0.017) .{ }^{21}$ Likewise, a study from a tertiary medical center in South Korea also demonstrated that underdosing of NOACs was associated with a 2.5-fold increased risk of thromboembolism compared with warfarin. ${ }^{20}$ 


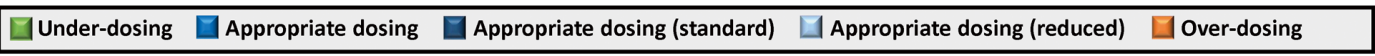

\section{Thromboembolic Events}

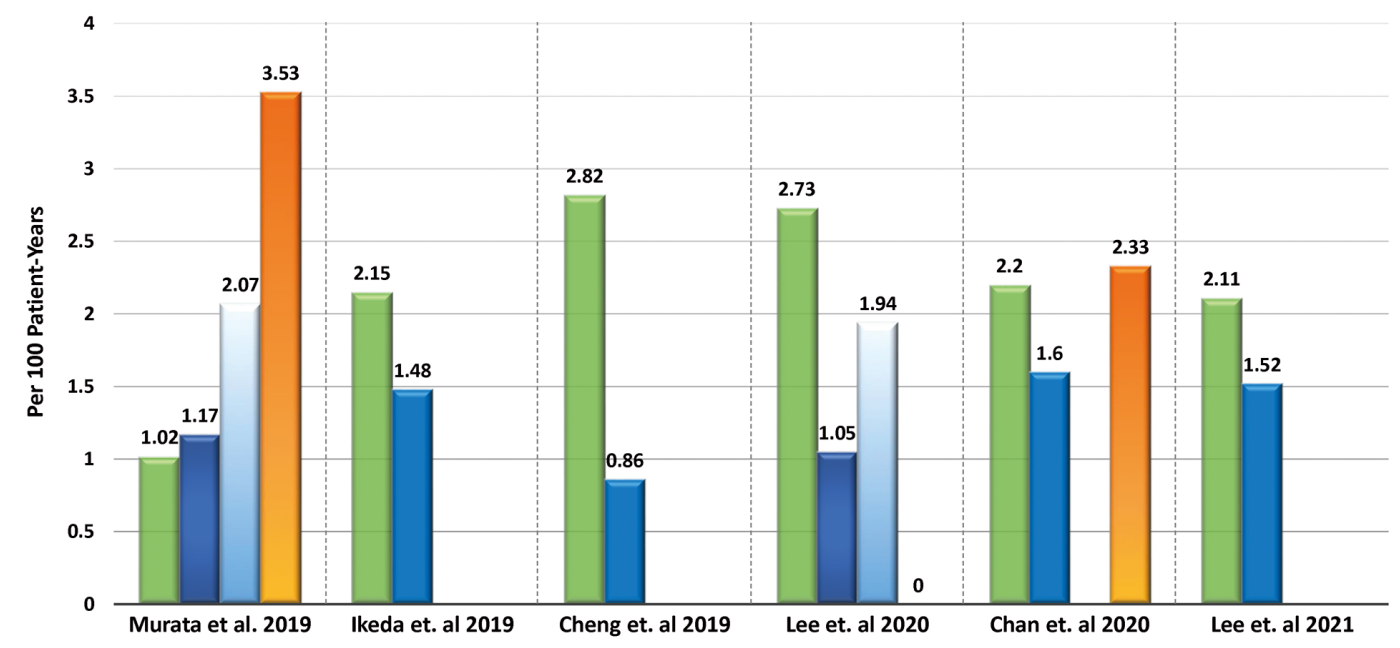

Major Bleeding

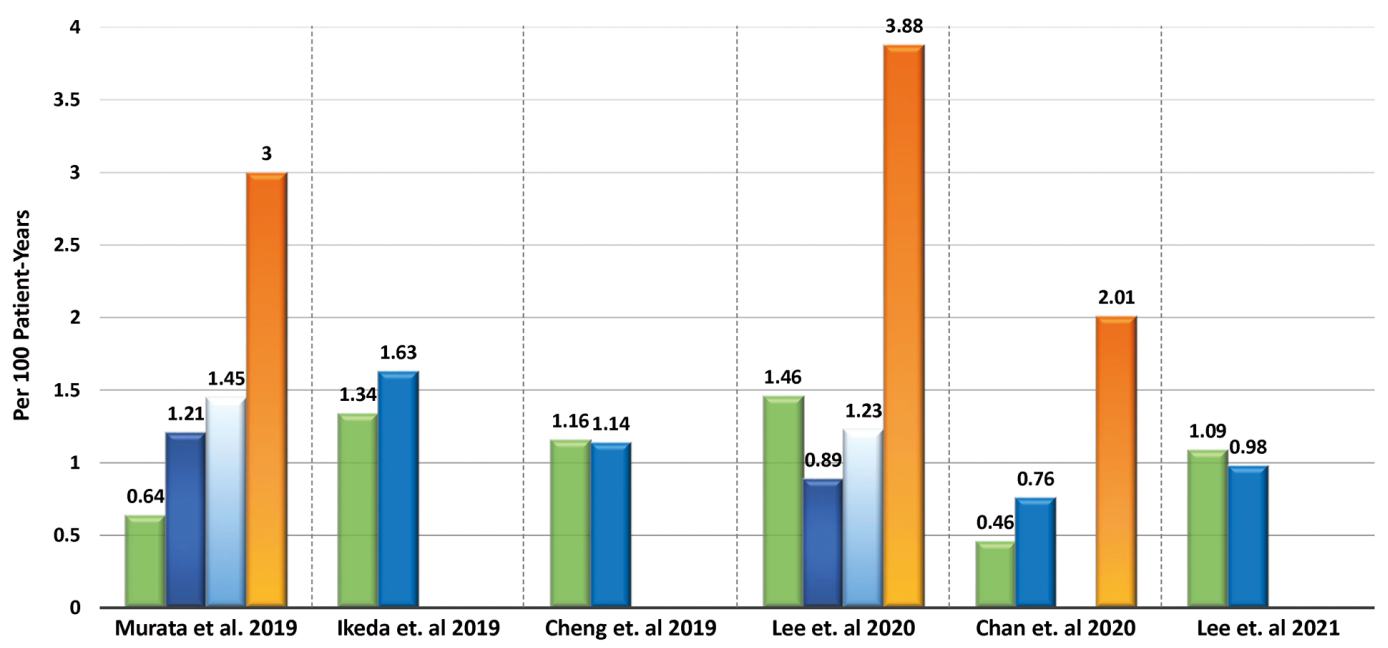

Figure 1. Risk of clinical events in Asian AF patients receiving on-labeling dosing, underdosing and overdosing of NOACs. Most studies demonstrate that underdosing is associated with a higher risk of ischemic stroke/systemic embolic events without a lower risk of major bleeding. On the other hand, overdosing is associated with a higher risk of major bleeding without a lower risk of ischemic events. The data used in the figure are from Cheng et al, ${ }^{11}$ Murata et al, ${ }^{18} \mathrm{Ikeda}$ et al, ${ }^{\mathbf{1 9}} \mathrm{Lee}$ et al, ${ }^{\mathbf{2 0}} \mathrm{Chan}$ et al, ${ }^{\mathbf{2 1}}$ and Lee et al. ${ }^{22} \mathrm{AF}$, atrial fibrillation; NOAC, non-vitamin $\mathrm{K}$ antagonist oral anticoagulant.

The dosing issue of rivaroxaban is even more complicated in Asia, where the J-ROCKET dosing criteria $(15 \mathrm{mg} /$ day for patients with an estimated glomerular filtration rate $(\mathrm{eGFR})>50 \mathrm{~mL} / \mathrm{min}$ and $10 \mathrm{mg} /$ day for those having an eGFR $<50 \mathrm{~mL} / \mathrm{min}$ ) were approved by Japan and the Taiwan Food and Drug Administration according to results of the J-ROCKET AF study. ${ }^{23}$ A prior study showed generally similar efficacy and safety profiles between the ROCKET-AF and J-ROCKET dosing regimens. ${ }^{24}$ Although J-ROCKET dosing of rivaroxaban may be also regarded as on-label dosing for Asian AF patients, off-label underdosing of rivaroxaban $(10 \mathrm{mg} /$ day for patients with an eGFR $>50 \mathrm{~mL} / \mathrm{min}$ ) was associated with a higher risk of IS and should generally be avoided. Data from the XAPASS (Xarelto Post-Authorization Safety and Effectiveness Study in Japanese Patients with Atrial Fibrillation) registry disclosed that $\approx 35.8 \%$ of Japanese AF patients with an eGFR $>50 \mathrm{~mL} / \mathrm{min}$ received underdosing of rivaroxaban $(10 \mathrm{mg} / \mathrm{day})$, which was associated with a higher composite risk of IS/SE/MI compared with the recommended dose ( 2.15 vs. 1.48 events/100 patient-years, $\mathrm{P}=0.009) .{ }^{19}$ Of note, the incidence rates of major bleeding 


\begin{tabular}{|c|c|c|c|c|}
\hline $\begin{array}{l}\text { Clinical } \\
\text { studies }\end{array}$ & $\begin{array}{l}\text { Definition of each renal function } \\
\text { assessment equation }\end{array}$ & Study type & $\begin{array}{l}\text { Total no. of } \\
\text { patients }\end{array}$ & Main findings \\
\hline $\begin{array}{l}\text { Lee et al } \\
(2019)^{29}\end{array}$ & $\begin{array}{l}\mathrm{CG}(\mathrm{mL} / \mathrm{min})=(140-\text { Age }) \times \text { Weight } /(72 \times \mathrm{SCr}) \\
\times(0.85 \text { if female }) \\
\mathrm{MDRD}\left(\mathrm{mL} / \mathrm{min} / 1.73 \mathrm{~m}^{2}\right)=175 \times \mathrm{SCr}-1.154 \times \\
\text { Age }-0.203 \times(0.742 \text { if female }) \times(1.210 \text { if } \\
\text { African-American })\end{array}$ & Retrospective & 6,268 & $\begin{array}{l}\text { 1. Among underweight and elderly patients, the } \\
\text { CG formula underestimated renal function } \\
\text { compared with the non-CG formulas } \\
\text { 2. The concordant rate of drug indications } \\
\text { between the CG and non-CG formulas was } \\
\text { approximately } 94 \% \\
\text { 3. The differences in eGFR and categorized } \\
\text { dose indications are unlikely to affect the risk } \\
\text { of thromboembolism or major bleeding in } \\
\text { on-label use of a NOAC }\end{array}$ \\
\hline $\begin{array}{l}\text { Chan et al } \\
(2020)^{30}\end{array}$ & $\begin{array}{l}\text { CKD-EPI }\left(\mathrm{mL} / \mathrm{min} / 1.73 \mathrm{~m}^{2}\right)=141 \times \min \\
(\mathrm{SCr} /(0.7 \text { if female; } 0.9 \text { if male }), 1)(-0.329 \\
\text { if female; }-0.411 \text { if male }) \times \max (\mathrm{SCr} /(0.7 \\
\text { if female; } 0.9 \text { if male }), 1)-1.209 \times 0.993 \\
\text { Age } \times(1.018 \text { if female }) \times(1.159 \text { if black })\end{array}$ & Retrospective & 39,239 & $\begin{array}{l}\text { 1. Compared with the CG equation, the MDRD } \\
\text { and CKD-EPI formulas overestimated eGFRs } \\
\text { in older adult AF patients with low body } \\
\text { weights } \\
\text { 2. The adoption of MDRD or CKD-EPI, rather } \\
\text { than CG, resulted in inappropriate dosing of } \\
\text { DOACs, thus attenuating the advantages of } \\
\text { DOACs compared with warfarin regarding the } \\
\text { composite risks of IS/SE and major bleeding }\end{array}$ \\
\hline
\end{tabular}

CG, Cockcroft-Gault; CKD-EPI, Chronic Kidney Disease Epidemiology Collaboration; MDRD, Modification of Diet in Renal Disease; SCr, serum creatinine. Other abbreviations as in Table 1.

were similar between the underdosing and standard dosing groups ( 1.34 vs. 1.63 events/100 patient-years, $\mathrm{P}=0.197) .{ }^{19}$ Similar findings were reported by Cheng et al, showing that off-label low-dose rivaroxaban was associated with an increased risk of IS with an HR of 2.75 (95\% CI 1.62-4.69; $\mathrm{P}<0.001)$, while the risk of intracranial hemorrhage did not differ significantly between the on-label and off-label lowdosing groups (HR 0.62; 95\% CI 0.32-1.20; $\mathrm{P}=0.213) .{ }^{11} \mathrm{~A}$ higher risk of IS was also observed for off-label underdosing of apixaban in a report from South Korea. ${ }^{22}$ Based on these studies, label-adherence to NOAC dosing should be emphasized to achieve the best clinical outcomes for Asian patients with AF.

\section{NOAC Dosing in Patients With Renal Dysfunction: Do Different Renal Function Equations Matter?}

Unlike warfarin, NOACs are prescribed at a fixed dose according to well-defined dosage reduction criteria of the individual NOAC. Therefore, the eGFR is crucial for the determination of the appropriate dose of NOAC. There are several equations (e.g., Cockcroft-Gault [CG], Modification of Diet in Renal Disease [MDRD] and the National Kidney Foundation recommended Chronic Kidney Disease Epidemiology Collaboration [CKD-EPI]) that are commonly used to calculate eGFR in the daily practice, but only the CG method was adopted in 4 pivotal randomized clinical trials. ${ }^{25-28}$ The 2 studies investigating differences of eGFRs calculated using different equations and the effect on appropriate NOACs dosing and subsequent clinical outcomes are summarized in Table 2.29,30 Both studies showed that non-CG formulas would overestimate eGFR compared with the CG equation, especially for the elderly and patients with a low body weight. Figure 2 demonstrates the eGFRs calculated using different equations for patients stratified by age and body weight based on data reported by Chan et al. ${ }^{30}$ Taking patients aged 75-79 years for example, the mean eGFR is lower than $50 \mathrm{~mL} / \mathrm{min}$ when calculated using $\mathrm{CG}$, but higher than $50 \mathrm{~mL} / \mathrm{min}$ calculated using the MDRD or CKD-EPI equations.

Chan et al further reported that in comparison with the CG formula, both the MDRD and CKD-EPI formulas could cause inappropriate dosing of NOACs (mainly overdosing), which would attenuate the advantages of NOACs. ${ }^{30}$ These findings were different from those reported by Lee et al, showing that despite the discrepancy in eGFR between the different equations, the risks of thromboembolic events and major bleeding were similar, irrespective of which formula was used. ${ }^{29}$ In daily practice, the CG formula should be used to calculate eGFR to determine the dosage of NOACs as the randomized clinical trials did, unless more high-quality studies can prove the usefulness of the non-CG equations in the future.

\section{Assessment of NOAC-Related Bleeding Risks}

Although NOACs are vital for AF-related stroke prevention, they can confer excess risk of bleeding. To date, several bleeding risk scores have been published, such as the modified Hypertension, Age, Stroke, Bleeding tendency/ predisposition, Labile international normalized ratios (INRs), Elderly age, Drugs or alcohol excess (HASBLED), ${ }^{31,32}$ the Anticoagulation and Risk Factors in Atrial Fibrillation (ATRIA), ${ }^{33-35}$ and the Outcomes Registry for Better Informed Treatment of Atrial Fibrillation (ORBIT) scores. ${ }^{35-37}$ Of these various risk scoring systems, HASBLED is recommended by important international guidelines, ${ }^{38} \mathbf{4 0}$ and is possibly the most validated scoring system, being applied for the prediction of bleeding risk whether AF patients are on no antithrombotic therapy, antiplatelet agents or OACs. ${ }^{35,41,42}$ Besides, the HAS-BLED score reliably performs the best by including labile INRs as a component for AF patients with warfarin therapy. ${ }^{35}$

It is important to emphasize that a high bleeding risk score should not in itself guide treatment decisions to use OAC for stroke prevention, which has been clearly mentioned in the 2020 ESC AF guidelines. ${ }^{40}$ The HAS-BLED score should be considered as an aid to addressing modifiable bleeding risk factors, and to identify patients at high 

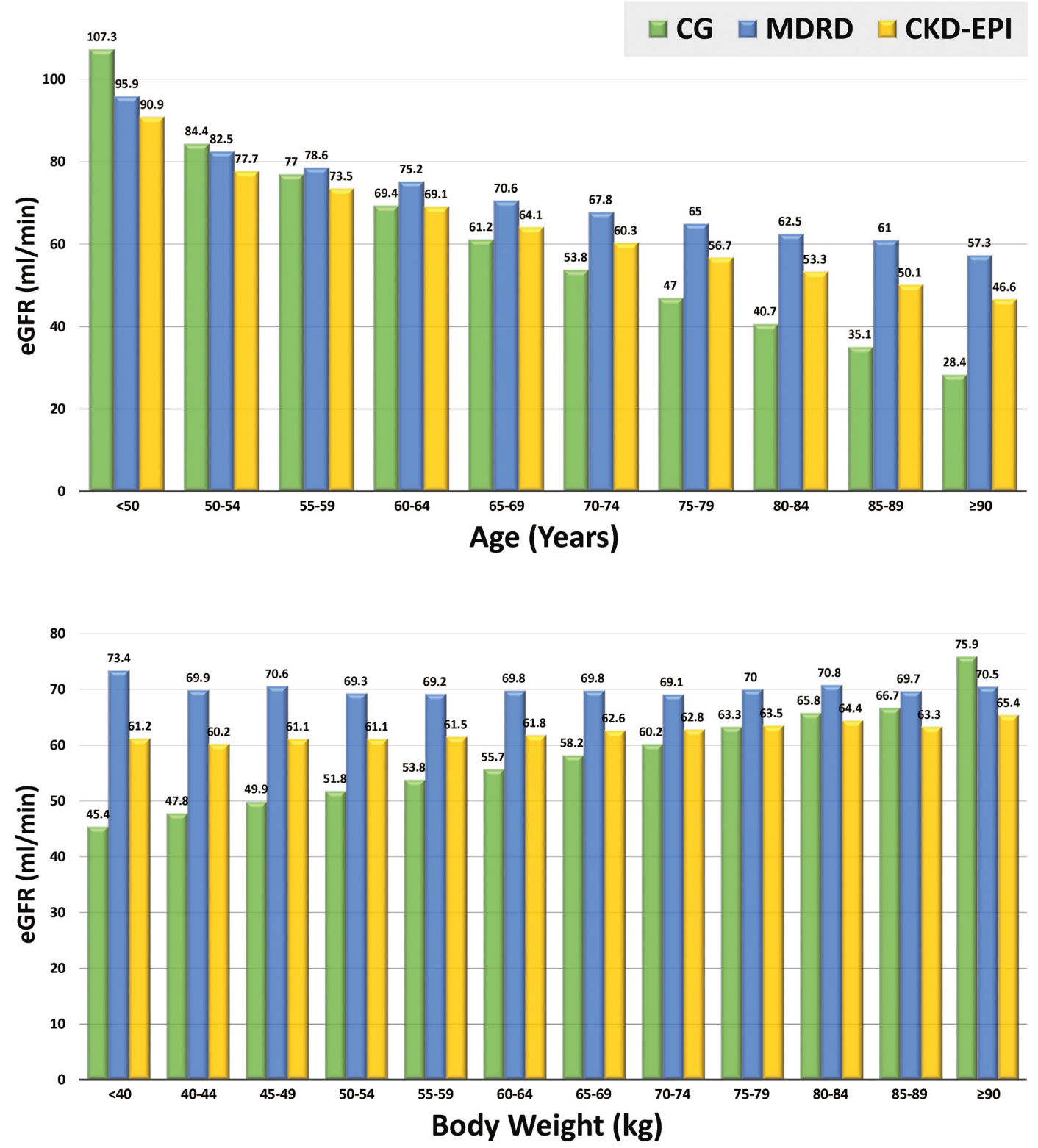

Figure 2. eGFRs calculated using different equations in different age and body weight strata. Compared with the CG formula, the MDRD and CKD-EPI equations overestimate the eGFR of AF patients, especially in the elderly and those with a low body weight. The data used in the figure are from Chan et al. ${ }^{30} \mathrm{AF}$, atrial fibrillation; CG, Cockcroft-Gault; CKD-EPI, Chronic Kidney Disease Epidemiology Collaboration; eGFR, estimated glomerular filtration rate; MDRD, Modification of Diet in Renal Disease.

risk of bleeding (HAS-BLED score $\geq 3$ ) for early and more frequent clinical review and follow-up. ${ }^{40} \mathrm{~A}$ recent study by Chao et al ${ }^{43}$ investigated 24,990 AF patients aged $\geq 20$ years with a $\mathrm{CHA}_{2} \mathrm{DS}_{2}$-VASc score $\geq 1$ (males) or $\geq 2$ (females) and a HAS-BLED score of $0-2$ who were treated with OACs. At end of 1 year, 5,229 (20.9\%) patients had an increment of their HAS-BLED score to $\geq 3$ and became a high-risk population for bleeding. Among 4,777 patients who consistently had a HAS-BLED score $\geq 3$, patients remaining on OACs (77.8\%) even after their HAS-BLED score increased to $\geq 3$ were associated with a lower risk of IS, major bleeding, all-cause death, and any adverse events. ${ }^{43}$ These findings support the concept that a high bleeding risk score should not be the only reason to withhold OACs, but reminds physicians to correct modifiable bleeding risk factors and follow up patients more closely.

The 2020 ESC guidelines also recommend that the bleeding risk should be reassessed at periodic intervals to address potentially modifiable bleeding risk factors ${ }^{40}$ because the bleeding risk of $\mathrm{AF}$ patients is not static. ${ }^{44} \mathrm{In}$ the mobile atrial fibrillation application (mAFA-II) randomized trial, dynamic risk monitoring using the HASBLED score, together with holistic App-based management using mAFA-II, significantly reduced bleeding events, 


\begin{tabular}{|c|c|c|c|c|}
\hline $\begin{array}{l}\text { Clinical } \\
\text { study }\end{array}$ & Study type & No. of patients & $\begin{array}{l}\text { OAC(s) } \\
\text { studied }\end{array}$ & Main findings \\
\hline $\begin{array}{l}\text { Yu et al } \\
(2017)^{62}\end{array}$ & Retrospective & $\begin{array}{l}5,833 \text { patients, } 3,798(65 \%) \text { were on } \\
\text { OACs (OAC }(+) \text { group) and } 2,035 \\
(35 \%) \text { were not (OAC (-) group) }\end{array}$ & Warfarin & $\begin{array}{l}\text { 1. GU cancer was more common in patients with } \\
\text { OACs compared with those without, in the whole } \\
\text { groups and after propensity score matching } \\
\text { 2. Bladder cancer was the most common GU } \\
\text { malignancy and was significantly more common } \\
\text { in the OACs group } \\
\text { 3. Patients with OACs were more likely to have } \\
\text { bladder cancers of low pathologic grade, } \\
\text { suggesting early detection of the malignancy } \\
\text { 4. Age }>75 \text { years, male sex, and gross hematuria } \\
\text { were associated with increased risk of GU } \\
\text { cancer. }\end{array}$ \\
\hline $\begin{array}{l}\text { Flack et al } \\
(2017)^{63}\end{array}$ & $\begin{array}{l}\text { Sub-analysis of } \\
\text { prospective trial } \\
\text { (RE-LY trial) }\end{array}$ & $\begin{array}{l}546 \text { anticoagulated patients } \\
\text { experiencing major Gl bleeding }\end{array}$ & $\begin{array}{l}\text { Warfarin } \\
\text { Dabigatran }\end{array}$ & $\begin{array}{l}\text { 1. Approximately } 1 \text { of every } 12 \text { major GI bleeding } \\
\text { events was related to an occult cancer } \\
\text { 2. Approximately two-thirds of cancer-related major } \\
\text { GI bleeding presented with chronic bleeding, } \\
\text { and morbidity, and resource utilization was high }\end{array}$ \\
\hline $\begin{array}{l}\text { Chang et al } \\
(2020)^{64}\end{array}$ & Retrospective & $\begin{array}{l}10,845 \text { anticoagulated AF patients } \\
\text { experiencing Gl bleeding }\end{array}$ & $\begin{array}{l}\text { Warfarin } \\
\text { Dabigatran } \\
\text { Rivaroxaban } \\
\text { Apixaban }\end{array}$ & $\begin{array}{l}\text { 1. At } 1 \text { year after } \mathrm{Gl} \text { bleeding, incident } \mathrm{Gl} \text { cancers } \\
\text { were diagnosed in } 1 \text { in } 37 \text { patients treated with } \\
\text { OACs } \\
\text { 2. More patients treated with NOACs were diag- } \\
\text { nosed as having GI cancer than those treated } \\
\text { with warfarin }(3.87 \% \text { vs. } 2.44 \% ; \mathrm{P}<0.001 \text {; odds } \\
\text { ratio } 1.606 ; \mathrm{P}<0.001) \\
\text { 3. Age and male sex were clinical factors associ- } \\
\text { ated with the diagnosis of Gl cancer after GI } \\
\text { bleeding } \\
\text { 4. The } 1 \text {-year risk of all-cause death after GI } \\
\text { cancers was lower among NOACs users who } \\
\text { experienced Gl bleeding than among warfarin } \\
\text { users }\end{array}$ \\
\hline $\begin{array}{l}\text { Raposeiras } \\
\text { Roubín et al } \\
\text { (2020)65 }\end{array}$ & Retrospective & $\begin{array}{l}8,753 \text { patients with } A F \text { aged } \geq 75 \text { years. } \\
\text { Of them, } 2,171(24.8 \%) \text { experienced } \\
\text { any clinically relevant bleeding, and } \\
479(5.5 \%) \text { were diagnosed with } \\
\text { cancer during a follow-up of } 3 \text { years }\end{array}$ & $\begin{array}{l}\text { Warfarin } \\
\text { Dabigatran } \\
\text { Rivaroxaban } \\
\text { Apixaban }\end{array}$ & $\begin{array}{l}\text { 1. In patients with } \mathrm{AF} \text { treated with OACs, any GI, } \\
\text { GU, or bronchopulmonary bleeding was associ- } \\
\text { ated with higher rates of new cancer diagnosis }\end{array}$ \\
\hline
\end{tabular}

$\mathrm{AF}$, atrial fibrillation; GI, gastrointestinal; GU, genitourinary; NOAC, non-vitamin $\mathrm{K}$ antagonist oral anticoagulant; OAC, oral anticoagulant.

addressed modifiable bleeding risks, and increased the uptake of OACs.

Another important factor requiring regular re-evaluation is renal function. In the Randomized Evaluation of LongTerm Anticoagulation Therapy (RE-LY) trial analysis, $24.2 \%$ patients were detected as having deteriorating renal function, which leads to higher risks of all-cause death and major bleeding. ${ }^{45}$ Consistent with the RE-LY trial analysis, Fauchier et al further showed that bleeding events were accentuated with deteriorating renal function by quartiles. ${ }^{46}$ Therefore, the 2018 European Heart Rhythm Association Practical Guide on the use of NOACs suggests follow up renal function at 6-month intervals for elderly or fragile patients. ${ }^{5}$ Furthermore, the suggested rechecking interval (months) equals "eGFR/10" for patients with a baseline eGFR $<60 \mathrm{~mL} / \mathrm{min} .{ }^{5}$ Once a patient's renal function has declined, we should try to survey for any correctable causes and adjust the dosing of NOACs if necessary based on the dosage reduction criteria of each NOAC.

\section{Management of NOAC-Related Bleeding}

Because NOACs have become more and more ubiquitous in AF patients, NOAC-related bleeding management is an important issue. When facing a NOAC-related bleeding event, closely and thoroughly reviewing the appropriate
NOAC's dosing is crucial, ${ }^{\mathbf{5}}$ and clinicians should also reevaluate any modifiable bleeding risk factors, including suboptimally treated hypertension, excessive alcohol intake and potential drug-drug interactions. ${ }^{47}$

Acute management of NOAC-related bleeding is mainly based on the severity and precise analysis of the patient's condition, which can be further divided into (1) minor bleeding, (2) hemodynamically stable major bleeding, and (3) life-threatening major bleeding. General principles of acute NOAC-related bleeding management consist of withholding NOACs to wane, non-specific hemostasis treatment such as blood products transfusion and antifibrinolytics, ${ }^{48}$ and specific NOAC reversal agents. Of note, neither vitamin $\mathrm{K}$ nor protamine has proven effective in dealing with NOAC-related bleeding. ${ }^{47}$

\section{Minor Bleeding}

Minor bleeding often prompts localization of the bleeding foci, which can be then treated accordingly. For instances, clinicians may prescribe proton pump inhibitors for AF patients with a NOAC and ulcer-related bleeding. In addition, epistaxis and gum bleeds could be treated with local compression and antifibrinolytics.

For patients with recurrent minor bleeding, switching to another NOAC might be considered in order to maintain effective stroke prevention, although data are limited. Last 


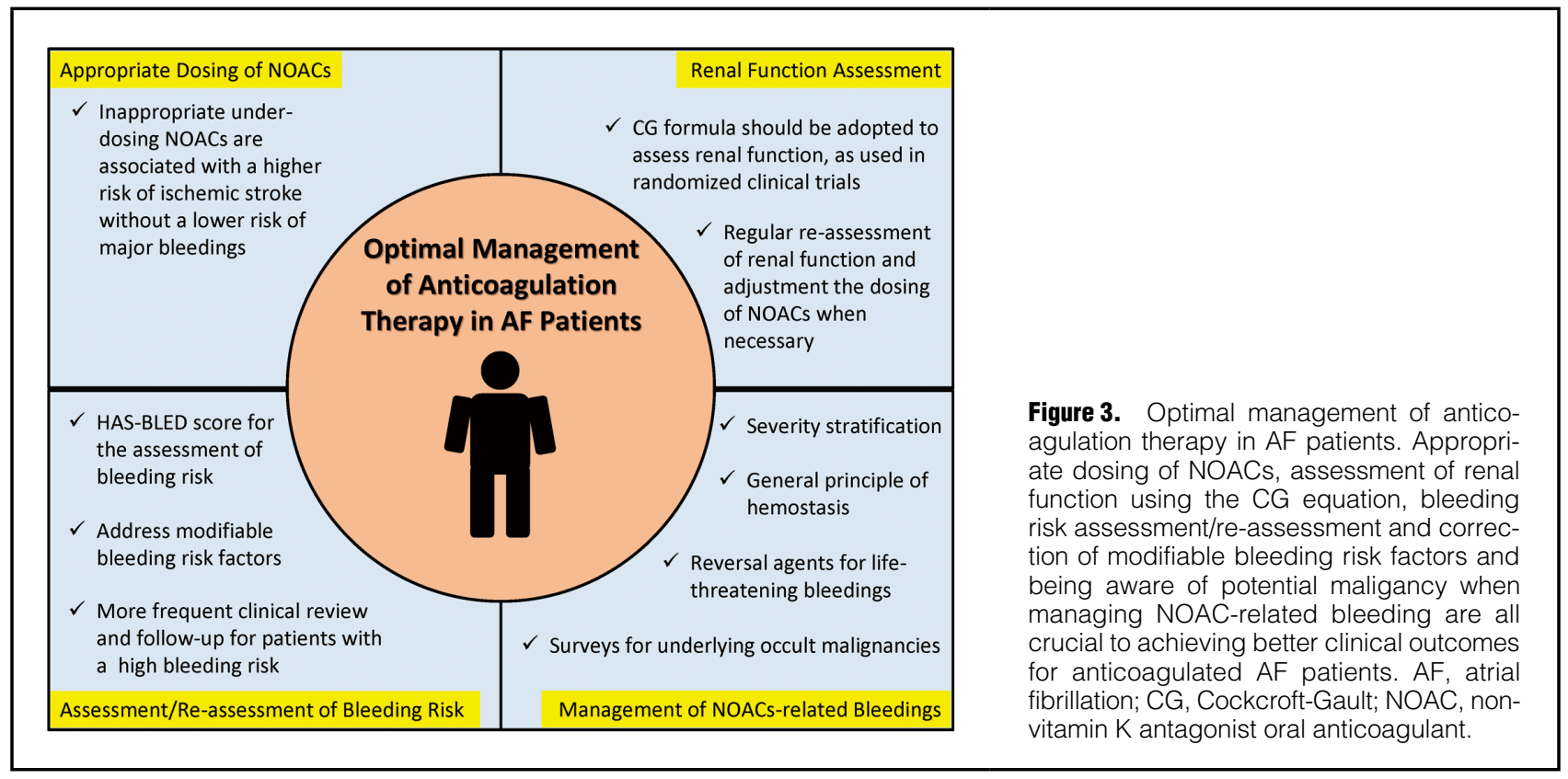

but not the least, a detailed and systemic work-up of possible causes should always be conducted.

\section{Hemodynamically Stable Major Bleeding}

Best supportive treatment, including mechanical compression, surgical hemostasis, fluid/blood products replacement and other non-specific hemostatic medications, is the cornerstone of managing hemodynamically stable major bleeding. Because the half-lives of NOACs are relatively short, the clinical condition is likely to improve with time. ${ }^{49}$

Another much-discussed issue is the effect of dialysis on NOAC-related bleeding, especially hemodynamically stable major bleeding. Several studies have proven the efficacy of dialysis when dealing with dabigatran-induced hemodynamically stable major bleeding, ${ }^{50,51}$ because approximately $80-85 \%$ of dabigatran is excreted by the kidney. ${ }^{52}$ On the other hand, dialysis is less likely to be beneficial for AF patients treated with factor $\mathrm{Xa}$ inhibitors (rivaroxaban, apixaban, and edoxaban), owing to the higher degree of protein-binding affinities. ${ }^{53,54}$

\section{Life-Threatening Major Bleeding}

In addition to all aforementioned measures, administration of specific NOAC reversal agents has been proved to have better clinical outcomes.

- Idarucizumab

Idarucizumab is the first introduced reversal agent for the NOAC dabigatran. In the RE-VERSal Effects of Idarucizumab on Active Dabigatran (REVERSE-AD) study, idarucizumab demonstrated its efficacy in treating patients with life-threatening major bleeding events as it successfully and rapidly reversed the anticoagulation effect of dabigatran in all patients. ${ }^{55} \mathrm{It}$ is suggested that a total of $5 \mathrm{~g}$ idarucizumab be given intravenously in 2 bolus doses of $2.5 \mathrm{~g}$ less than $15 \mathrm{~min}$ apart..$^{55}$

- Direct reversal of factor Xa inhibitors

In the Anticoagulation Effects of Factor Xa Inhibitors-4 (ANNEXA-4) study, andexanet $\alpha$ showed its efficacy in treating patients with factor $\mathrm{Xa}$ inhibitor-related life- threatening major bleeding events, as $82 \%$ of patients had excellent or good hemostatic efficacy at $12 \mathrm{~h} .{ }^{\mathbf{5 6}} \mathrm{It}$ is suggested that the drug be administered as a bolus over 15-30 min, followed by a 2 -h infusion. ${ }^{56}$

\section{Pay Attention to Occult Malignancies When Managing NOAC-Related Bleeding}

Although acute managements of NOACs-related bleeding is vital, an important issue that is easily overlooked is the existence of occult malignancies that are the cause/origin of the bleeding. In fact, in a pooled analysis of 4 randomized trials, malignancies were not uncommon in AF patients and accounted for $\approx 11 \%$ of mortality. ${ }^{57}$ In the Global Anticoagulant Registry in the Field-Atrial Fibrillation (GARFIELD-AF) registry, malignancy-related deaths accounted for $11.1 \%$ and $10.3 \%$ of all deaths at 1 year and 2 years, respectively. ${ }^{58,59}$ In a Danish Registry, Ostenfeld et al described a comparable rise of malignancies in $\mathrm{AF}$ patients. ${ }^{60}$ Given that malignancies and AF are highly correlated, early stratification of AF patients with high risk of malignancy is essential. Hung et al reported that age, male sex, hypertension, diabetes, chronic obstructive pulmonary disease and liver cirrhosis are the main risk factors of malignancies among AF patients, and surveys for early detection of possible occult malignancies may be considered for high-risk patients. ${ }^{61}$

Interestingly, NOAC-related bleeding could be the clinical presentation of an underlying cancer. Published studies regarding this issue are summarized in Table 3.62 65 In subanalyses of both the RE-LY and Cardiovascular OutcoMes for People using Anticoagulation StrategieS (COMPASS) trials, gastrointestinal (GI) bleeding was likely to be the first sign of GI malignancies in patients receiving NOACs. ${ }^{63,66}$ In a Taiwan nationwide study, incident GI cancers were diagnosed in 1 of $37 \mathrm{AF}$ patients at 1 year after OAC-related GI bleeding, and were more common among patients treated with NOACs $(1 / 26)$ compared with warfarin $(1 / 41){ }^{64}$ The risk of death was lower in patients treated with NOACs 
than in those treated with warfarin $(23.5 \%$ vs. $51.8 \%$; $\mathrm{P}<0.001$ ), suggesting that NOACs may disclose occult cancers through the presentation of bleeding at an earlier stage than with warfarin, because the intensity of warfarin therapy is often suboptimal among Asians. ${ }^{64}$ Similar findings have been reported for anticoagulated patients presenting with hematuria among whom the possibility of underlying bladder cancers should be kept in mind. ${ }^{62}$

\section{Conclusions}

In this review article, we have highlighted several important issues about the optimal management of anticoagulation in AF patients, which are summarized in Figure 3. Appropriate dosing of NOACs, assessment of renal function using the $\mathrm{CG}$ equation, bleeding risk assessment/reassessment and correction of modifiable bleeding risk factors, and being aware of potential maligancy when managing NOAC-related bleeding are all crucial to achieving better clinical outcomes for anticoagulated AF patients. More efforts are necessary to incorporate clear and easy-to-follow recommendations about optimal management of anticoagulation into the guidelines to improve $\mathrm{AF}$ patient care.

\section{Funding Sources / Conflict of Interest Disclosures}

None.

\section{Data Availability}

All data generated or analyzed during this study are included in this published article.

\section{References}

1. Chao TF, Liu CJ, Tuan TC, Chen TJ, Hsieh MH, Lip GYH, et al. Lifetime risks, projected numbers, and adverse outcomes in Asian patients with atrial fibrillation: A report from the Taiwan Nationwide AF Cohort Study. Chest 2018; 153: 453-466.

2. Lip GYH. Stroke and bleeding risk assessment in atrial fibrillation: When, how, and why? Eur Heart J 2013; 34: 1041 - 1049.

3. Lip GYH, Freedman B, de Caterina R, Potpara TS. Stroke prevention in atrial fibrillation: Past, present and future comparing the guidelines and practical decision-making. Thromb Haemost 2017; 117: 1230-1239.

4. Lip GYH. The ABC pathway: An integrated approach to improve AF management. Nat Rev Cardiol 2017; 14: 627-628.

5. Steffel J, Verhamme P, Potpara TS, Albaladejo P, Antz M, Desteghe L, et al. The 2018 European Heart Rhythm Association Practical Guide on the use of non-vitamin K antagonist oral anticoagulants in patients with atrial fibrillation. Eur Heart $J$ 2018; 39: 1330-1393.

6. Chao TF, Chiang CE, Lin YJ, Chang SL, Lo LW, Hu YF, et al. Evolving changes of the use of oral anticoagulants and outcomes in patients with newly diagnosed atrial fibrillation in Taiwan. Circulation 2018; 138: 1485-1487.

7. Ruff CT, Giugliano RP, Braunwald E, Hoffman EB, Deenadayalu $\mathrm{N}$, Ezekowitz MD, et al. Comparison of the efficacy and safety of new oral anticoagulants with warfarin in patients with atrial fibrillation: A meta-analysis of randomised trials. Lancet 2014; 383: $955-962$.

8. Cheng WH, Chiang CE, Lin YJ, Chang SL, Lo LW, Hu YF, et al. Non-vitamin $K$ antagonist oral anticoagulants in elderly ( $\geq 85$ years) patients with newly diagnosed atrial fibrillation: Changing clinical practice and outcomes for stroke prevention in a nationwide cohort study. Mayo Clin Proc 2021; 96: 52-65.

9. January CT, Wann LS, Calkins H, Chen LY, Cigarroa JE, Cleveland JC, et al. 2019 AHA/ACC/HRS focused update of the 2014 AHA/ACC/HRS guideline for the management of patients with atrial fibrillation: A Report of the American College of Cardiology/American Heart Association Task Force on Clinical Practice Guidelines and the Heart Rhythm Society. Heart Rhythm 2019; 16: e66-e93.
10. Ogilvie IM, Newton N, Welner SA, Cowell W, Lip GYH. Underuse of oral anticoagulants in atrial fibrillation: A systematic review. Am J Med 2010; 123: 638-645.e4.

11. Cheng WH, Chao TF, Lin YJ, Chang SL, Lo LW, Hu YF, et al. Low-dose rivaroxaban and risks of adverse events in patients with atrial fibrillation. Stroke 2019; 50: 2574-2577.

12. Cha MJ, Choi EK, Han KD, Lee SR, Lim WH, Oh S, et al. Effectiveness and safety of non-Vitamin $\mathrm{K}$ antagonist oral anticoagulants in Asian patients with atrial fibrillation. Stroke 2017; 48: $3040-3048$.

13. Larsen TB, Skjøth F, Nielsen PB, Kjældgaard JN, Lip GYH. Comparative effectiveness and safety of non-Vitamin K antagonist oral anticoagulants and warfarin in patients with atrial fibrillation: Propensity weighted nationwide cohort study. BMJ 2016; 353: 13189.

14. Maura G, Blotière PO, Billionnet KBC, Ricordeau P, Alla F, Zureik M. Comparison of the short-term risk of bleeding and arterial thromboembolic events in nonvalvular atrial fibrillation patients newly treated with dabigatran or rivaroxaban versus vitamin K antagonists: A French nationwide propensity-matched cohort study. Circulation 2015; 132: 1252-1260.

15. Sørensen R, Gislason G, Torp-Pedersen C, Olesen JB, Fosbøl EL, Hvidtfeldt MW, et al. Dabigatran use in Danish atrial fibrillation patients in 2011: A nationwide study. BMJ Open 2013; 3: $\mathrm{e} 002758$.

16. Basaran Ö, Dogan V, Beton O, Tekinalp M, Aykan AC, Kalaycioglu E, et al. Suboptimal use of non-vitamin K antagonist oral anticoagulants results from the RAMSES study. Med (United States) 2016; 95: e4672.

17. Steinberg BA, Shrader P, Thomas L, Ansell J, Fonarow GC, Gersh BJ, et al. Off-label dosing of non-vitamin $\mathrm{K}$ antagonist oral anticoagulants and adverse outcomes: The ORBIT-AF II registry. J Am Coll Cardiol 2016; 68: 2597-2604.

18. Murata N, Okumura Y, Yokoyama K, Matsumoto N, Tachibana $\mathrm{E}, \mathrm{Kur}$ unuma K, et al. Clinical outcomes of off-label dosing of direct oral anticoagulant therapy among japanese patients with atrial fibrillation identified from the SAKURA AF registry. Circ J 2019; 83: 727-735.

19. Ikeda T, Ogawa S, Kitazono T, Nakagawara J, Minematsu K, Miyamoto S, et al. Outcomes associated with under-dosing of rivaroxaban for management of non-valvular atrial fibrillation in real-world Japanese clinical settings. J Thromb Thrombolysis 2019; 48: 653-660.

20. Lee KN, Choi JI, Boo KY, Kim DY, Kim YG, Oh SK, et al. Effectiveness and safety of off-label dosing of non-vitamin $\mathrm{K}$ antagonist anticoagulant for atrial fibrillation in Asian patients. Sci Rep, doi:10.1038/s41598-020-58665-5.

21. Chan YH, Chao TF, Chen SW, Lee HF, Yeh YH, Huang YC, et al. Off-label dosing of non-vitamin $\mathrm{K}$ antagonist oral anticoagulants and clinical outcomes in Asian patients with atrial fibrillation. Heart Rhythm 2020; 17: 2102-2110.

22. Lee SR, Choi EK, Park SH, Jung JH, Han KD, Oh S, et al. Off-label underdosed apixaban use in Asian patients with nonvalvular atrial fibrillation. Eur Hear J Cardiovasc Pharmacother, doi:10.1093/ehjcvp/pvab004.

23. Hori M, Matsumoto M, Tanahashi N, Momomura SI, Uchiyama $\mathrm{S}$, Goto S, et al. Rivaroxaban vs. warfarin in Japanese patients with non-valvular atrial fibrillation in relation to age: Insight from J-ROCKET AF. Circ J 2014; 78: 1349-1356.

24. Chan YH, Lee HF, Wang CL, Chang SH, Yeh CH, Chao TF, et al. Comparisons of rivaroxaban following different dosage criteria (ROCKET AF or J-ROCKET AF Trials) in Asian patients with atrial fibrillation. J Am Heart Assoc 2019; 8: e013053.

25. Connolly SJ, Ezekowitz MD, Yusuf S, Eikelboom J, Oldgren J, Parekh A, et al. Dabigatran versus warfarin in patients with atrial fibrillation. $N$ Engl J Med 2009; 361: 1139-1151.

26. Granger CB, Alexander JH, McMurray JJV, Lopes RD, Hylek EM, Hanna M, et al. Apixaban versus warfarin in patients with atrial fibrillation. N Engl J Med 2011; 365: 981-992.

27. Patel MR, Mahaffey KW, Garg J, Pan G, Singer DE, Hacke W, et al. Rivaroxaban versus warfarin in nonvalvular atrial fibrillation. $N$ Engl J Med 2011; 365: 883-891.

28. Giugliano RP, Ruff CT, Braunwald E, Murphy SA, Wiviott SD, Halperin JL, et al. Edoxaban versus warfarin in patients with atrial fibrillation. $N$ Engl J Med 2013; 369: 2093-2104.

29. Lee KN, Choi JI, Kim YG, Boo KY, Kim DY, Choi YY, et al. Comparison of renal function estimation formulae for dosing direct oral anticoagulants in patients with atrial fibrillation. $J$ Clin Med 2019; 8: 2034.

30. Chan YH, Chao TF, Lee HF, Yeh YH, Yeh CH, Huang YC, et 
al. Impacts of different renal function estimation formulas on dosing of DOACs and clinical outcomes. $\mathrm{J} \mathrm{Am}$ Coll Cardiol 2020; 76: $1808-1810$.

31. Pisters R, Lane DA, Nieuwlaat R, DeVos CB, Crijns HJGM, LipGYH, et al. A novel user-friendly score (HAS-BLED) to assess 1-year risk of major bleeding in patients with atrial fibrillation: The euro heart survey. Chest 2010; 138: 1093-1100.

32. Lip GYH, Frison L, Halperin JL, Lane DA. Comparative validation of a novel risk score for predicting bleeding risk in anticoagulated patients with atrial fibrillation: The HAS-BLED (hypertension, abnormal renal/liver function, stroke, bleeding history or predisposition, labile INR, elderly, drugs/alcohol concomitantly) score. J Am Coll Cardiol 2011; 57: 173-180.

33. Fang MC, Go AS, Chang Y, Borowsky LH, Pomernacki NK, Udaltsova $\mathrm{N}$, et al. A new risk scheme to predict warfarin-associated hemorrhage: The ATRIA (Anticoagulation and Risk Factors in Atrial Fibrillation) Study. J Am Coll Cardiol 2011; 58: 395-401.

34. Roldán V, Marín F, Fernández H, Manzano-Fernandez S, Gallego P, Valdés M, et al. Predictive value of the HAS-BLED and ATRIA bleeding scores for the risk of serious bleeding in a "real-world" population with atrial fibrillation receiving anticoagulant therapy. Chest 2013; 143: 179-184.

35. Senoo K, Proietti M, Lane DA, Lip GYH. Evaluation of the HAS-BLED, ATRIA, and ORBIT bleeding risk scores in patients with atrial fibrillation taking warfarin. Am J Med 2016; 129: $600-607$.

36. O'Brien EC, Simon DN, Thomas LE, Hylek EM, Gersh BJ, Ansell JE, et al. The ORBIT bleeding score: A simple bedside score to assess bleeding risk in atrial fibrillation. Eur Heart $J$ 2015; 36: ehv476.

37. Lip GYH, Skjøth F, Nielsen PB, Kjældgaard JN, Larsen TB. The HAS-BLED, ATRIA, and ORBIT bleeding scores in atrial fibrillation patients using non-vitamin $\mathrm{K}$ antagonist oral anticoagulants. Am J Med 2018; 131: 574.e13-574.e27.

38. Chiang CE, Okumura K, Zhang S, Chao TF, Siu CW, Lim TW, et al. 2017 consensus of the Asia Pacific Heart Rhythm Society on stroke prevention in atrial fibrillation. J Arrhythmia 2017; 33: $345-367$.

39. Lip GYH, Banerjee A, Boriani G, Chiang CE, Fargo R, Freedman $\mathrm{B}$, et al. Antithrombotic therapy for atrial fibrillation: CHEST guideline and expert panel report. Chest 2018; 154: 1121-1201.

40. Hindricks G, Potpara T, Dagres N, Arbelo E, Bax JJ, BlomströmLundqvist C, et al. 2020 ESC Guidelines for the diagnosis and management of atrial fibrillation developed in collaboration with the European Association for Cardio-Thoracic Surgery (EACTS). Eur Heart J 2021; 42: 373-498.

41. Chao TF, Lip GYH, Lin YJ, Chang SL, Lo LW, Hu YF, et al. Major bleeding and intracranial hemorrhage risk prediction in patients with atrial fibrillation: Attention to modifiable bleeding risk factors or use of a bleeding risk stratification score? A nationwide cohort study. Int J Cardiol 2018; 254: 157-161.

42. Apostolakis S, Lane DA, Guo Y, Buller H, Lip GYH. Performance of the HEMORR 2HAGES, ATRIA, and HAS-BLED bleeding risk-prediction scores in patients with atrial fibrillation undergoing anticoagulation: The AMADEUS (Evaluating the use of SR34006 compared to warfarin or acenocoumarol in patients with atrial fibrillation) study. $J$ Am Coll Cardiol 2012; 60: $861-867$.

43. Chao TF, Chan YH, Chiang CE, Tuan TC, Liao JN, Chen TJ, et al. Continuation or discontinuation of oral anticoagulants after HAS-BLED scores increase in patients with atrial fibrillation. Clin Res Cardiol, doi:10.1007/s00392-021-01816-z.

44. Chao TF, Lip GYH, Lin YJ, Chang SL, Lo LW, Hu YF, et al. Incident risk factors and major bleeding in patients with atrial fibrillation treated with oral anticoagulants: A comparison of baseline, follow-up and delta HAS-BLED scores with an approach focused on modifiable bleeding risk factors. Thromb Haemost 2018; 118: 768-777.

45. Hijazi Z, Hohnloser SH, Oldgren J, Andersson U, Connolly SJ, Eikelboom JW, et al. Efficacy and safety of dabigatran compared with warfarin in patients with atrial fibrillation in relation to renal function over time: A RE-LY trial analysis. Am Heart $J$ 2018; 198: 169-177.

46. Fauchier L, Bisson A, Clementy N, Vourc'h P, Angoulvant D, Babuty $\mathrm{D}$, et al. Changes in glomerular filtration rate and outcomes in patients with atrial fibrillation. Am Heart J 2018; 198:
$39-45$.

47. Kirchhof P, Benussi S, Kotecha D, Ahlsson A, Atar D, Casadei $\mathrm{B}$, et al. $2016 \mathrm{ESC}$ Guidelines for the management of atrial fibrillation developed in collaboration with EACTS. Eur Heart $J$ 2016; 37: 2893-2962.

48. Beyer-Westendorf J, Förster K, Pannach S, Ebertz F, Gelbricht $\mathrm{V}$, Thieme $\mathrm{C}$, et al. Rates, management, and outcome of rivaroxaban bleeding in daily care: Results from the Dresden NOAC registry. Blood 2014; 124: 955-962.

49. Levi M, Eerenberg E, Kamphuisen PW. Bleeding risk and reversal strategies for old and new anticoagulants and antiplatelet agents. J Thromb Haemost 2011; 9: 1705-1712.

50. Stangier J, Rathgen K, Sthle H, Mazur D. Influence of renal impairment on the pharmacokinetics and pharmacodynamics of oral dabigatran etexilate: An open-label, parallel-group, singlecentre study. Clin Pharmacokinet 2010; 49: 259-268.

51. Getta B, Muller N, Motum P, Hsu D, Zebeljan D, Rosenfeld D Intermittent haemodialysis and continuous veno-venous dialysis are effective in mitigating major bleeding due to dabigatran. $\mathrm{Br}$ J Haematol 2015; 169: 603-604.

52. Knauf F, Chaknos CM, Berns JS, Perazella MA. Dabigatran and kidney disease: A bad combination. Clin J Am Soc Nephrol 2013; 8: 1591-1597.

53. Parasrampuria DA, Marbury T, Matsushima N, Chen S, Wickremasingha PK, He L, et al. Pharmacokinetics, safety, and tolerability of edoxaban in end-stage renal disease subjects undergoing haemodialysis. Thromb Haemost 2015; 113: 719-727.

54. Wang X, Tirucherai G, Marbury TC, Wang J, Chang M, Zhang $\mathrm{D}$, et al. Pharmacokinetics, pharmacodynamics, and safety of apixaban in subjects with end-stage renal disease on hemodialysis. J Clin Pharmacol 2016; 56: 628-636.

55. Pollack CV, Reilly PA, vanRyn J, Eikelboom JW, Glund S, Bernstein RA, et al. Idarucizumab for dabigatran reversal: Full cohort analysis. $N$ Engl J Med 2017; 377: 431-441.

56. Connolly SJ, Crowther M, Eikelboom JW, Gibson CM, Curnutte JT, Lawrence JH, et al. Full study report of andexanet alfa for bleeding associated with factor Xa inhibitors. N Engl J Med 2019; 380: $1326-1335$.

57. Gómez-Outes A, Lagunar-Ruíz J, Terleira-Fernández AI, CalvoRojas G, Suárez-Gea ML, Vargas-Castrillón E. Causes of death in anticoagulated patients with atrial fibrillation. $\mathrm{J} \mathrm{Am} \mathrm{Coll} \mathrm{Cardiol}$ 2016; 68: $2508-2521$.

58. Bassand JP, Accetta G, Camm AJ, Cools F, Fitzmaurice DA, Fox KAA, et al. Two-year outcomes of patients with newly diagnosed atrial fibrillation: Results from GARFIELD-AF. Eur Heart J 2016; 37: 2882-2889.

59. Bassand JP, Virdone S, Goldhaber SZ, Camm AJ, Fitzmaurice DA, Fox KAA, et al. Early risks of death, stroke/systemic embolism, and major bleeding in patients with newly diagnosed atrial fibrillation. Circulation 2019; 139: 787-798.

60. Ostenfeld EB, Erichsen R, Pedersen L, Farkas DK, Weiss NS, Sørensen HT. Atrial fibrillation as a marker of occult cancer. PLoS One 2014; 9: e102861.

61. Hung YP, Hu YW, Liu CJ, Lin YJ, Chang SL, Lo LW, et al. Risk and predictors of subsequent cancers of patients with newly-diagnosed atrial fibrillation: A nationwide populationbased study. Int J Cardiol 2019; 296: 81-86.

62. Yu HT, Kim TH, Uhm JS, Kim JY, Pak HN, Lee MH, et al. Clinical significance of hematuria in atrial fibrillation with oral anticoagulation therapy. Circ J 2017; 81: 158-164.

63. Flack KF, Desai J, Kolb JM, Chatterjee P, Wallentin LC, Ezekowitz M, et al. Major gastrointestinal bleeding often is caused by occult malignancy in patients receiving warfarin or dabigatran to prevent stroke and systemic embolism from atrial fibrillation. Clin Gastroenterol Hepatol 2017; 15: 682-690.

64. Chang TY, Chan YH, Chiang CE, Lin YJ, Chang SL, Lo LW, et al. Risks and outcomes of gastrointestinal malignancies in anticoagulated atrial fibrillation patients experiencing gastrointestinal bleeding: A nationwide cohort study. Heart Rhythm 2020; 17: 1745-1751

65. Raposeiras Roubín S, Abu Assi E, Barreiro Pardal C, Cespón Fernandez M, Muñoz Pousa I, Cobas Paz R, et al. New cancer diagnosis after bleeding in anticoagulated patients with atrial fibrillation. J Am Heart Assoc 2020; 9: e016836.

66. Eikelboom JW, Connolly SJ, Bosch J, Shestakovska O, Aboyans $\mathrm{V}$, Alings $\mathrm{M}$, et al. Bleeding and new cancer diagnosis in patients with atherosclerosis. Circulation 2019; 140: 1451-1459. 